\title{
Educational Development of NGO Beneficiaries in Bangladesh: A Disjunction between Programmes and Implementation
}

\author{
Mohammad Aktaruzzaman Khan ${ }^{1,2}$, Md. Aminul Islam³ \& Anees Janee Ali ${ }^{2}$ \\ ${ }^{1}$ Department of Business Administration, IIUC, Bangladesh \\ ${ }^{2}$ School of Management, USM, Malaysia \\ ${ }^{3}$ School of Business Innovation and Technopreneurship, Universiti Malaysia Perlis (Unimap), Malaysia \\ Correspondence: Mohammad Aktaruzzaman Khan, Department of Business Administration, IIUC, Bangladesh. \\ E-mail: rajarkul2002@yahoo.com
}

Received: June 25, 2014 Accepted: July 25, 2014 Online Published: October 30, 2014

doi:10.5539/ass.v10n22p57 URL: http://dx.doi.org/10.5539/ass.v10n22p57

\begin{abstract}
This study examines the relationship between NGO programmes and their clients' educational development. NGOs play a very significant role with a view to achieving their development goal. Developing countries consider education as the key aspect for their socio-economic development. The study focuses on this perspective and asks the relationship between NGOs' socio-economic and training programmes (by Kirkpatrick's training taxonomy) and educational development of their beneficiaries. A quantitative research approach was employed to investigate this relationship. A total of 300 responses from three leading NGOs were analysed using multiple regression analysis. The results suggest that NGOs' informal education and two training dimensions (learning and behaviour) contribute significantly to their clients' education while health, micro-credit, and the other training dimensions (reaction and result) have on effect. These findings have implications for strategic roles of NGOs also for future research in filling the gap between their programmes and implementation.
\end{abstract}

Keywords: NGOs, health, education, micro-credit, training, socio-economic development

\section{Introduction}

In the year 2000, 189 UN member states set eight millennium development goals (MDG), focused at human development that centered on the development of education, health, and income components to be reached by 2015. In the way of achieving these, developed nations have been contributing their aid to poor nations. However, the recent Human Development Report (HDR) stated that for the past 15 years there has been a low quantity of development aid and less relationship with the targeted development. Moe (2008) found that foreign development assistance is targeted to support socio-economic development and has significant positive association with human development. So, readdressing the aid mechanism through extensive socio-economic programmes of the foreign development organisations, especially non-government, is an urgent priority of the recipient countries. The quality and effectiveness of development organisations will have a direct impact on the success on those development programmes, particularly on education sector.

A few studies conducted on the educational development, mostly in a top-down fashion where NGOs' own target and efficacy for their donor organisations are highlighted and beneficiaries' demand is neglected. On the other hand, NGOs' aid allocation for poverty alleviation as the means of economic development is extremely scarce (Dreher, Mölders, \& Nunnenkamp, 2010), initiated for other than socio-economic purposes (Alesina \& Dollar, 2000; Katayama, 2007), consequently, brought insignificant development in Bangladesh (Fruttero \& Gauri, 2005). There has been a lack of empirical studies of the effectiveness of development aids, through non-governmental organisations (NGOs), and its impacts on educational development in Bangladesh, and not much is known about it. Training is the intermediary means to materialise the NGO intervention in the implementation of development programmes among their beneficiaries. In order to improve development programmes of NGOs, this study conducts an empirical investigation into the relationship between the select-NGOs' training programmes and educational development of NGO beneficiaries. The findings and results of this study will benefit major key stakeholders, including donors, and NGO decision-makers of the recipient countries who play a major role in the development process. Human resources (HR) managers and NGO 
decision-makers in Bangladesh have been challenged to report the programme effectiveness of training. This article explores Bangladeshi NGO experiences from a cross-sectional perspective to understand better training evaluation issues towards educational development of their beneficiaries.

\section{Literature Review}

\subsection{Development and Socio-economic Development}

In measuring the socio-economic development, a number of indicators prevailed in development studies which constitute influence on the development of NGO beneficiaries. Beneficiaries refer to the clients who are benefited by the socio-economic and training programmes of NGOs. Davies (1998) defined development as outside intervention or "aided" development, and the definition of socio-economic development is given by Jaffee as the "ability to produce an adequate and growing supply of goods and services productively and efficiently, to accumulate capital, and to distribute the fruits of production in a relatively equitable manner (Jaffee, 1998)". International bodies have been set up some components or categories of development indicators to promote. WHO promotes health, FAO agriculture, UNIDO industry, UNESCO education, and UNCTAD promotes trade. Consequently, a number of indicators have been taken into account by studies in common for socio-economic development such as income, nutrition, health, education, and housing (McGranahan, Richard-Proust, Sovani, \& Subramanian, 1972; Rao, 1976; FAO, 1988).

\subsection{Educational Development}

Kofi Annan, the former UN Secretary General, depicted 'education' as a human right having huge transformation power bases in freedom, democracy, and sustainable human development (UNICEF, 1999). In other view, Katayama also regards education as human right (Katayama, 2007). In this study, the authors take the former perspective of education into consideration. In Bangladesh, education plays a significant role towards the socio-economic development of their people. Denison empirically studied the economic growth of U.S. ranging from 1929 to 1957 in order to examine the role of education as determinants. The findings suggested that during this period America's economic growth could not be explained by production factors in traditional economics (i.e., physical capital, labour, and land), rather explained by the advance of knowledge through education or human capital (Denison, 1962). In a subsequent research finding, Denison expressed that during 1950 to 1962, $23 \%$ of America's economic growth was to the improvement of education among labour forces (Denison, 1967). In a similar way, the economic growth in East Asia was for the improvement of the educational level of the labour force, and the growth of capital rather than technological progress (Krugman, 1994).

Using the rate of return analysis of education, the study also investigated the role of education pertaining to the economic growth at micro level. The notion of human capital developed by the renowned economists such as Schultz, Becker, Mincer, and Rees contributed to the evolution of the rate of return analysis of education. Schultz's conceptualisation of private benefit of education in economic growth employed the cost of education as well as forgone earnings, individual's income and the social benefit of education (Schultz, 1963, pp. 5-11) also supported by Rees as Schultz's concept of private and social benefits of education is significant for developing countries (Rees, 1979). In the following year, based on Schultz's conceptualisation, Becker established the theoretical framework of rate of return analysis of education in the form of private rate and social rate (Becker, 1964). In a similar vein, Psacharopoulos (1994) opined that the number one investment priority in developing countries is primary education and investment in women's education is more profitable than that for men. Hence, educational development is the key to the socio-economic indication of NGO beneficiaries in Bangladesh, one of the representative countries of developing world.

\subsection{Health}

Almost half a century ago, WHO defined health as "a state of complete physical, mental and social well-being and not merely the absence of disease or infirmity" (Breslow, 1972; WHO, 2006; Jadad \& O'Grady, 2008). Health and poverty are closely correlated as illness can cause poverty through a downward helix of income loss, treatment costs and asset diminution. This constitutes the single largest factor associated with descending households (Ravaillion, 1998; Sen, 2003). To what extent health expenditures can affect poverty, is well manifested into large and unpredictable health payments. This brings significant financial risk which, in turn, results in impoverishment also related to the triangle of poverty (Xu et al., 2003). Besides, the interconnected health and poverty in regard to transitory poverty, health hazards can also cause chronic poverty if illness impacts the capacity of households to escape poverty (Wagstaff, 2002). So, the above factors limit the educational attachment of NGO clients. 


\subsection{Micro-credit}

Micro-Credit Summit Campaign, in 2002, reported that nearly 23,000 registered NGOs (Haque, 2002) have been operating particularly aiming to alleviation of rural poverty (Ullah \& Routray, 2007) as the means of socio-economic development in Bangladesh. Among the registered NGOs, 92 per cent are involved in micro-credit services of which $90 \%$ of small NGOs and $96 \%$ are big NGOs (Gauri \& Galef, 2005).

Hulme and Moore opined that the evidence of social impact of micro-credit in Bangladesh is partial and contested, but on balance, suggests that micro-credit have positive social and economic effects (Hulme, 2000). This is also supported by a strand of researches on impact assessment study on micro-credit (Pitt, Khandker, Chowdhury, \& Millimet, 2003; Rahman, 1996; as cited in Ahmed, 2009). Khandaker noted that micro-credit programmes promote investment in human capital and raise awareness of reproductive health issues; he also found positive economic impact on clients in terms of income growth and reduced vulnerability (Khandker, 1999).

Zaman, Hassan, Annamalai, Nagavalli, Appasamy Irajen et al. (2005) demonstrated that the share of aid to NGOs as a portion of total aid to Bangladesh has increased from $14.4 \%$ in the early 1990 s to $24.5 \%$ in the years between 1996 and 2004. It is regretful that only about 10-25 percent of donor funds actually reach the poorest (Yunus, 1999; as cited in Ahmed, 2009) and the big NGOs reach only 10-20 per cent of the landless households (Zaman, 1996), therefore, the impact of micro-credit programmes on the socio-economic development is partial and contested (Hulme, 2000).

\subsection{Training}

A Chinese proverb says "To plan one year, saw seed; to plan ten years, plant trees; and to plan 100 years, develop human resources". So, development of human capital through training is not a short-term strategy rather it should be addressed from the long-term perspective (Dhakal \& Nawaz, 2009). The definition of training does not change so much from one researcher to another. Noe (2008) defined training as planned effort by a company to facilitate employees' learning of job competencies. These competencies include knowledge, skills and attitude (behaviour) that are critical for organisational success.

Arend, examining one of the biggest South African NGOs, opined that the organisation has focused predominantly on meeting the demands of its donors, and subsequently has had limited capacity to meet its growing needs in regard to human resources and organisational development (Arend, 2008). In a study on 20 development NGOs in Bangladesh, Huda, Karim, \& Ahmed (2007) found NGOs were facing shortage of qualified candidates, inadequate qualified female candidate, and poor academic background of applicants in the suburban and rural areas. More significantly, lack of training infrastructure and paucity of training need analysis which is directly concerned with the socio-economic and human resource development of their beneficiaries.

Human resource development is, still, an emerging area of research in the third world countries and has not received proper attention in Bangladesh (Mahmood, 2004). Surprisingly, an inadequate number of studies have been conducted in this area so far in Bangladesh context (Mahmood, 2004; Absar \& Mahmood, 2011), however, due attention on training and development is absent. This still remains an unearthed area for research. Moreover, few researches conducted by local researchers which were not supported theoretically as well as empirically.

\subsection{Kirkpatrick's Four-level Taxonomy}

Kirkpatrick's classic four-level training evaluation model has been examined often (Alliger \& Janak, 1989; Holton, 2005; McLean, 2005). Kirkpatrick's (1998) four levels include: (1) Level I-reaction: measures how learners feel about learning/training; (2) Level II-learning: evaluates what was learned and retained from the learning experience; (3) Level III-behaviour/application: evaluates the degree to which learners apply what was learned on the job; and (4) Level IV-results: evaluates the impact that transfer of learning has on the business. Krein and Weldon (1994) suggested that the four levels attempt to answer the following questions: (1) Level1: how the participants feel about the training; (2) Level 2: what the participants acquired from the training; (3) Level 3: how much participants applied what they have learnt? and (4) Level 4: how much company gains from this exercise (Khan \& Ali, 2014).

Though, there is three-dimensional criticism exists in the literature (Alliger, Tannenbaum, Bennett, Traver, \& Shotland, 1997; McLean, 2005), Kirkpatrick's model of training evaluation has had widespread and enduring popularity because of its simplicity and its ability to help people think about training evaluation criteria (Alliger \& Janak, 1989). Training evaluation has been an important subject in management studies and research as it is related to the issues of efficiency, effectiveness, and impact (Rossi \& Freeman, 1989; Kirkpatrick, 2005; Giangreco, Carugati, \& Sebastiano, 2010). 
Based on the literature review, the authors propose a conceptual framework for studying beneficiaries' educational development throwing light on several variables of interest that would have impact on development NGOs of Bangladesh, and the variables that have not been extensively and comprehensively studied in any past research. This framework emphasises on the following predictor variables: health, education, micro-credit, and four-training dimensions to address the underlying research question leading to educational development for the socio-economic capacity building of NGO beneficiaries (Figure 1). In the way of addressing these research questions, the study examined the following research hypotheses which have been derived from components of the three constructs under study.

\section{Hypotheses}

H1: The NGOs' socio-economic programmes (health, education, \& micro-credit) significantly related to the beneficiaries' educational development;

H1.1 The NGOs' health programme is positively related to the beneficiaries' education;

H1.2 The NGOs' education programme is positively related to the beneficiaries' education;

H1.3 The NGOs' micro-credit programme is negatively related to the beneficiaries' education;

H2: The NGOs' training programmes (reaction, learning, behaviour, \& result) significantly related to the beneficiaries' educational development;

H2.1 The NGOs' training-reaction is positively related to the beneficiaries' education;

H2.2 The NGOs' training-learning is positively related to the beneficiaries' education;

H2.3 The NGOs' training-behaviour is positively related to the beneficiaries' education;

H2.4 The NGOs' training-result is positively related to the beneficiaries' education.

\section{Significance of the Study}

This study is significant for the following reasons:

Contribution to the theory: Little is known about the relationship between NGOs' socio-economic and training programmes and their beneficiaries' educational development. Use of the Becker's human capital theory and Kirkpatrick's four-dimensional evaluation model of training to assess the NGOs' educational development will add value to development studies at the individual level of analysis, especially, in the NGO sector in Bangladesh. Additionally, this empirical study is among few to examine NGO-clients' educational advancement in a bottom-up fashion.

Contribution to practice: The study identifies linkages between their designed programmes and educational development. Through this study, such linkage may enables NGOs to reduce costs associated with need assessment for training and give emphasise more on shifting their focus from simply economic to comprehensive socio-economic aspects which, in turn, increase the effectiveness of their programmes.

\section{Theoretical Framework}

The study uses two well-grounded theories to measure the relationship between socio-economic and training programmes and educational development: Becker's (1964) human capital theory, and Kirkpatrick's (1998) four-level taxonomy of training evaluation.

A theoretical framework used to ground, or anchor the study focusing on the relationship between NGOs' socio-economic and training programmes and educational development of their beneficiaries in Bangladesh. The study is divided into three categories of variables: NGOs' socio-economic and training variables and beneficiaries' educational development.

\section{Methods}

The quantitative approach utilized survey methodology with associational correlational-descriptive, field-based, and cross-sectional study. This research, based on the purpose, is an applied or action research which is exploratory in nature, since, very few studies have been conducted in this arena. So, the motivation is to assess the NGOs' socio-economic and training programmes which will impact socio-economic capacity building of their clients through education.

\subsection{Study Variables}

The study examined beneficiaries' education as consequence of NGOs' socio-economic and training programmes. Hence, beneficiaries' education was the dependent variable under investigation. The three NGOs' 
socio-economic programmes (underlined by Becker's human capital theory) and training programmes (conceptualised in Kirkpatrick's four-level taxonomy-reaction, learning, behaviour, and result) were considered as possible predictors, hence, independent variables of beneficiaries' educational advancement.

\subsection{Subjects and Site}

The target population for this study included three leading NGO beneficiaries who were provided training and socio-economic programmes. This study has excluded the NGO-respondents with the following characteristics: (1) respondents from two large development organisations: Grameen Bank and ASA (The Association of Social Advancement); (2) the respondents who got the training less than two months and more than two years; and (3) respondents who were not benefited through other socio-economic programmes such as health, education, and micro-credit at least between one year and two years for this analysis. The restricted probability multi-stage stratified sampling (Sekaran, 2003) was chosen as the sampling design because the 'NGO beneficiaries' had to fulfil certain criteria in order to qualify as respondents. The focus of this study was only three large NGOs who fulfil the criteria covering socio-economic and training programmes. Grameen Bank and ASA were dropped from the list of preference, since, Grameen Bank is neither NGO nor traditional bank (Nabi, Alam, Jahur, \& Quadir, 1997, p. 5); on the other hand, ASA also similar to Grameen Bank operating only micro-credit having no training programmes for which did not fall within the purview of the research interest of this study.

The three development NGOs of Bangladesh were studied in this research. These three leading NGOs were established in the years 1972, 1976, and 1958 having operations in 64, 64, and 36 (out of 68 administrative districts of the country) districts, respectively. They also have staff strength of 46,674 (NGO A) and 4,240 (NGO C) in the executive and non-executive level. NGO B also has activities in most of the districts and in 24,213 villages and 2,110 slums throughout the country. The rationale of selecting these leading NGOs is based on their coverage capacity, maturity of programmes and huge number of clients involved in multi-dimensional non-profit activities.

\subsection{Procedure}

The study is based on a self-report survey design, using cross-sectional data, acquired through questionnaires. The survey questionnaires were distributed among select NGO beneficiaries through field workers of randomly selected sample VOs (village organisation, a team consisting of 20-30 female members) under three districts (administrative units of the country) employing multi-stages stratified sampling method. Babbie and Rahman report that to carry out a pragmatic investigation into a large population like NGO sector in Bangladesh-the 'multi-stages stratified sampling' method is suitable and mostly used for survey among NGO beneficiaries (Babbie, 1995; Rahman, 2005). A total of 400 questionnaires were distributed among the sample areas. A total of 318 completed questionnaires were received, and after removing the ones with missing data, 300 usable questionnaires emerged ( $75 \%$ response rate).

\subsection{Measures}

The data used for this study were obtained through Kirkpatrick's (1998) four dimensional model of training evaluation underlying Becker's (1964) human capital theory. Demographic information items were also included for sample description. The following measures have been used to conduct the survey.

- The three dimensions of socio-economic programmes are represented by 16 items derived from Jahur, Absar, and Sultana (2002) consisting of four adopted, five adapted, and seven constructed. Five items assess health, four items assess education, and seven items assess micro-credit, respectively.

- The four dimensions of training evaluation is represented by 28 items derived from Barker (1997), Barcala, Martin, and Gutierrez (2000), Wilson (2000), Pau (2001), Price (2001), Tai (2006), and Al-Eisa, Furayyan, and Alhemoud (2009), consisting of three adopted, 20 adapted, and five constructed to measure NGOs' training programmes. 11 items assess training-reaction, seven items assess training-learning, five items assess training-behaviour, and five items assess training-result.

- Beneficiaries' educational development is represented by a four-item scale (adapted) derived from McGranahan, et al., (1972), Rao (1976), and FAO (1988) that measures the NGO-beneficiaries' educational status.

- Seven demographic items-genders, age, marital status, number of children, education, occupation, and experience with NGO activities-were included in the survey to facilitate the interpretation of the results.

\subsection{Unit of Analysis}

Nardi (2003, p. 98) defines unit of analysis as 'the element about which you are observing and collecting data, 
such as a person responding to a questionnaire, a school, an editorial, or a local business'. The study variables measured at the individual level, as unit of analysis which is integral to research design. Each individual and each subject treated as an individual source (Sekaran, 2010).

\subsection{Statistical Analysis}

Three types of statistical analysis were conducted for this study using SPSS 19.0. First, factor analysis was conducted to determine construct validity, fit, and appropriateness of the instrument (Fraenkel \& Wallen, 2000). Second, for three instruments, internal reliability analysis using Cronbach's alpha was used to determine the reliability of all scales (Cronbach \& Furby, 1970). Third and finally, multiple regression analysis was conducted to examine the relationship between predictor and criterion variables as highlighted in the research framework to test the research hypotheses. More specifically, multiple regression analysis was employed to identify the relationship between NGOs' socio-economic and training dimensions (independent variables) and beneficiaries' educational development (dependent variables).

\section{Results}

\subsection{Demographic Profile of the Respondents}

The study has received 300 sets of completed questionnaires of which about 99 per cent are dominantly female and married. About 40.7 per cent respondents were aged between 26 and 35 years old and 68.3 per cent had three and above number of children. Most of the respondents were uneducated (59 per cent), and 34.3 per cent of the respondents were below secondary level. Overall, there were 46.3 per cent of the respondents are attached to NGO activities for less than five years category and 47 per cent felt in the range of 11 to 15 years. In terms of occupation, 50.7 per cent were attached to small business, 32 per cent were from agriculture sector while only 9.3 per cent were self-employed.

\subsection{Factor Analyses of Study Variables}

Principal component factor analyses using the Varimax rotation option were employed to conduct factor analysis to determine the basic structure (Hair, Black, Babin, \& Anderson, 2010) as well as dimensionality (Sekeran \& Bougie, 2010) of the study variables. NGOs' three dimensional socio-economic items, four-component training evaluation items, and beneficiaries' education level items were factor analysed using Varimax rotation.

The factor analysis of first construct of independent variables (health, education, and micro-credit) is presented as Table 1. A three-factor solution emerged dropping three items (out of 16) explaining 57.60 per cent of the total variance in three socio-economic dimensions. The KMO measure of sampling adequacy was .728 indicating sufficient inter-correlations while the Bartlett's Test of Sphericity was significant (Chi square $=1235.348, p<$ $0.01)$.

Table 1. Rotated factor and factor loadings for three socio-economic programmes

\begin{tabular}{llll}
\hline Factors of socio-economic programmes & \multicolumn{2}{l}{ Components } & \multicolumn{2}{l}{} \\
\hline micro credit1 & $\mathbf{1}$ & $\mathbf{2}$ & .252 \\
micro credit3 & $\mathbf{. 5 4 0}$ & .193 & -.091 \\
micro credit4 & $\mathbf{. 6 4 6}$ & .000 & -.014 \\
micro credit5 & $\mathbf{6 9 8}$ & -.090 & .227 \\
micro credit7 & $\mathbf{. 8 2 4}$ & .020 & .015 \\
education1 & $\mathbf{. 8 8 2}$ & -.074 & .058 \\
education2 & -.026 & $\mathbf{. 8 1 3}$ & -.061 \\
education3 & -.050 & $\mathbf{. 8 1 5}$ & .255 \\
education4 & .046 & $\mathbf{. 7 2 6}$ & .203 \\
health1 & .018 & $\mathbf{. 6 7 3}$ & $\mathbf{. 7 7 7}$ \\
health3 & -.062 & .018 & $\mathbf{. 8 1 0}$ \\
health4 & .064 & .088 & $\mathbf{. 8 8 9}$ \\
health5 & .028 & .221 & $\mathbf{. 6 2 4}$ \\
Percentage of variance & .191 & .095 & 57.60 \\
KMO & & & .728 \\
Approximate $X^{2}$ & & & $235.35^{* * *}$
\end{tabular}

Note: $* * * p<0.01$ 
The second construct of independent variables (reaction, learning, behaviour, and result) is presented as Table 2 . A four-factor solution emerged dropping seven items (out of 28) explaining 72.18 per cent of the total variance in four training dimensions. The KMO measure of sampling adequacy was .808 indicating sufficient inter-correlations while the Bartlett's Test of Sphericity was significant (Chi square $=4702.560, p<0.01$ ).

The result of the analysis on the dependent variable (beneficiaries' education) is shown as Table 3 . All items loaded on to one factor (dropping one item) where the total variance explained was 71.294 per cent. The KMO measure of sampling adequacy was .627 indicating sufficient inter-correlations while the Bartlett's Test of Sphericity was significant (Chi square $=2424.815, p<0.01$ ).

Table 2. Rotated factor and factor loadings for four training dimensions

\begin{tabular}{lllll}
\hline Items & Factor & & & \\
& $\mathbf{1}$ & $\mathbf{2}$ & $\mathbf{3}$ & $\mathbf{4}$ \\
\hline reaction1 & $\mathbf{. 7 8 6}$ & .168 & .149 & .072 \\
reaction2 & $\mathbf{. 9 5 5}$ & .117 & -.014 & .087 \\
reaction3 & $\mathbf{. 8 6 2}$ & .101 & .014 & .059 \\
reaction5 & $\mathbf{. 1 0}$ & .081 & -.007 & .035 \\
reaction6 & $\mathbf{. 7 1 4}$ & .053 & -.006 & .034 \\
reaction7 & $\mathbf{. 8 5 9}$ & .169 & .105 & .070 \\
reaction11 & $\mathbf{. 7 5 2}$ & .133 & .016 & .088 \\
result1 & .171 & $\mathbf{. 8 4 0}$ & -.002 & .015 \\
result2 & .063 & $\mathbf{. 8 7 4}$ & -.029 & -.102 \\
result3 & .108 & $\mathbf{. 6 9 6}$ & -.084 & -.021 \\
result4 & .185 & $\mathbf{. 8 8 7}$ & -.031 & -.026 \\
result5 & .171 & $\mathbf{. 7 2 4}$ & .153 & .040 \\
behaviour1 & .242 & .096 & $\mathbf{. 6 0 9}$ & .085 \\
behaviour2 & -.041 & .050 & $\mathbf{. 8 4 4}$ & -.029 \\
behaviour3 & -.006 & -.036 & $\mathbf{. 8 2 8}$ & -.081 \\
behaviour4 & .125 & -.011 & $\mathbf{. 5 6 4}$ & .134 \\
behaviour5 & -.010 & -.029 & $\mathbf{. 9 3 0}$ & .005 \\
learning1 & .064 & .023 & .065 & $\mathbf{. 8 4 9}$ \\
learning3 & .159 & -.083 & .079 & $\mathbf{. 7 9 7}$ \\
learning4 & .008 & -.050 & .010 & $\mathbf{. 9 0 4}$ \\
learning7 & .074 & .016 & -.056 & $\mathbf{. 6 6 4}$ \\
Percentage of variance & & & 72.179 & \\
KMO & & & .808 & \\
Approximate $X^{2}$ & & & $4702.56 * * *$ & \\
\hline Note & & & & \\
\hline
\end{tabular}

Note: $* * * p<0.01$

Table 3. Factor loadings for beneficiaries' educational development

\begin{tabular}{ll}
\hline Items & $\begin{array}{l}\text { Factor } \\
\text { Beneficiaries' education }\end{array}$ \\
\hline Education1 & .938 \\
Education2 & .939 \\
Education3 & .606 \\
Percentage of variance & 71.294 \\
KMO & .627 \\
Approximate $X^{2}$ & $2424.815^{* * *}$ \\
\hline Note: $* * * p<0.01$ &
\end{tabular}




\subsection{Reliability Analysis}

Next to factor analysis reliability is the second criterion that ensures goodness of measures. The study used Cronbach's alpha to conduct reliability analysis in order to determine the scale reliability (Table 4). The reliability coefficients for NGOs' socio-economic programmes-health, 0.73 ; education, 0.77 ; micro-credit, 0.78 , training programmes variables-reaction, 0.92 ; learning, 0.82 ; behaviour, 0.82 , result, 0.88 , and education of beneficiaries, 0.79; respectively, which exceed Nunnally's (1978) recommended threshold of 0.70 . Hence, the contention of the instruments used in this survey was both reliable, and valid as demonstrated by the factor analyses results.

Table 4. Reliability coefficient for model variables

\begin{tabular}{llll}
\hline Variables & Number of Items & Items Dropped & Chronbach's Alpha \\
\hline Socio-Economic Programmes & $\mathbf{1 6}$ & $\mathbf{3}$ & \\
Health & 5 & 1 & .73 \\
Education & 4 & -- & .77 \\
Micro-credit & 7 & 2 & .78 \\
Training Programmes & $\mathbf{2 8}$ & 7 & \\
Reaction & 11 & 4 & .92 \\
Learning & 7 & 3 & .82 \\
Behaviour & 5 & -- & .82 \\
Result & 5 & -- & .88 \\
Beneficiaries' education & 4 & 1 & .79 \\
\hline
\end{tabular}

\subsection{Regression Analysis}

\section{Socio-economic and training programmes towards education}

Table 5 presented the results of the regression analysis, showed a significant positive relationship between beneficiaries' educational development and NGOs' education programme $(\beta=.165, \mathrm{p}<.01)$, training-behaviour ( $\beta$ $=0.169, \mathrm{p}<.01)$, and training-learning $(\beta=0.117, \mathrm{p}<.05)$. The relationship between beneficiaries' education level and health $(\beta=0.041)$, micro-credit $(\beta=0.055)$ and training-result $(\beta=0.024)$, although positive, are not significant, while training-reaction is negatively associated with NGOs' educational development $(\beta=-0.030)$.

Table 5. Regression for beneficiaries' educational development

\begin{tabular}{ll}
\hline Independent Variables & Beneficiaries' Educational Development \\
\hline Health & .041 \\
Education & $.165^{* * *}$ \\
Micro-credit & .055 \\
Training-Reaction & -0.030 \\
Training-Learning & $.117^{* *}$ \\
Training-Behaviour & $.169^{* * *}$ \\
Training-Result & .024 \\
F-Value & 4.682 \\
$\mathrm{R}^{2}$ & .101 \\
Adjusted $\mathrm{R}^{2}$ & .080 \\
\hline
\end{tabular}

Note: ${ }^{* * *} p<.01,{ }^{* *} p<.05,{ }^{*} p<.10$

The regression results indicate that $\beta$ value of the regression for behaviour dimension (training programme) was greater $(\beta=0.169, \mathrm{p}<.01)$ than education $(\beta=.165, \mathrm{p}<.01)$ and learning $(\beta=0.117, \mathrm{p}<.05)$. So, NGOs' education and training programmes (behaviour and learning) are the best predictors for beneficiaries' education (dependent variable). Further, although the predictors are positively significant, together they explain only 10.0 per cent of 
the variance in beneficiaries' educational development, but these predictor variables make a unique contribution to explaining the dependent variable. Hence, hypotheses H1.2, H2.2 and H2.3 are accepted.

\section{Discussion}

The analytical results of the present research have shown that NGOs' education, learning, and behaviour have positively significant impact on NGO beneficiaries' perceptions regarding their educational development (Table 6). This result is supported by several previous studies (Hallak, 1990; Schiere, 2008), also through the lens of human capital theory (Schultz, 1963; Becker, 1964). Human capital theory suggests that expenditure on education and training in order to impart knowledge and developing skills increases the individual's (here beneficiaries) lifetime earnings and productivity with a view to achieving socio-economic capacity building in the society.

Contrarily, the present research has shown the insignificant relationship between health and beneficiaries' education which is opposite to the Becker's (1964) theory. Boissiere, et al. (1985) has validated the human capital theory using education data, where the researchers found that World Bank inculcated human capital theory in their education policy formulation for the developing countries. The descriptive analyses of beneficiaries' education may give explanation that shows quite low means and standard deviations $[2.73 \pm 0.81]$ compare to other dependent variables. It might be due to the insufficient presence of health-related education initiatives of NGOs. The insignificant result confirms the beneficiaries" perception such as "most of the adults in my family are able to read and write" not supported by their profile which is represented by $59 \%$ uneducated beneficiaries.

Likewise, the study result has shown insignificant association between micro-credit and beneficiaries' education. Nevertheless, the study finding was expected and supported by several previous studies where the impact of micro-credit programme of Bangladeshi NGOs was focused as partial and contested (Hulme, 2000; Ullah \& Routray, 2007; Ahmed, 2009). Though, the insignificant finding is opposite to Becker's (1964) human capital theory, several research findings have found influential roles of micro-credit on beneficiaries' education development such as children schooling, school enrolment (BIDS), girls' schooling (Pitt et al., 2003), and school enrolment rate and attitude to education.

The insignificant relationship between NGOs' first and fourth training dimension (reaction and result) and beneficiaries' educational development can be attributed to a number of reasons. Firstly, NGOs' lack of appropriate participants as most of the time the same beneficiaries were chosen in the capacity of being the team leader of VO (village organisation). Secondly, lack of training need analysis and inappropriate programme manifested in the first phase of training (reaction), and finally brought insignificant outcome to the last phase (result). McEvoy (1997) stated that trainees often tend to complete their training in a state of excitement, such that their immediate favourable reaction is much higher than feedback reactions measured later. In a similar vein, Dixon (1990) also concluded that good reactions do not necessarily transform to later phase-good learning. This justification affirmed by the authors of this study during data collection as well as by a number of other study findings (Brown \& Bessant, 2003; Dhakal \& Newaz, 2009).

Dhakal and Newaz (2009), in their cross national study on Bangladesh and Nepal, found inappropriate and insufficient human capital development programme in the line with Brown and Bessant's (2003) study wherein supportive, flexible, and multi-skilled workforce is sought. Otherwise, the NGOs cannot retain their critical staff for imparting training and knowledge to their beneficiaries (Ahmad, 2002; Ramlall, 2004). Consequently, lead to the shortage of qualified staff, inadequate qualified female fieldworkers needed in the suburban and rural areas will remain to continue (Huda et al., 2007), which will, in turn, bring their objective to achieve educational development of their beneficiaries into question.

\section{Future Research}

There is still dearth of research carried out on the dimensions of educational development. In order to design future research directions, a number of recommendations can be made.

It would be beneficial to conduct a longitudinal study in different geographical locations and cultures with more number of NGOs permitting both causal assessment and results generalization. As argued by O'Driscoll, Brough, and Kalliath (2004), the use of a longitudinal approach would essentially be able to determine whether the effects of the predictor variables persist over time.

In general, it is more acceptable if the R-square value in multiple regression analysis is higher. However, in the present study, the value for R-square in the regression is only 10.0 per cent. This can be explained that educational development can be explained by the other predictors such as human capability, network, 
socio-organisational, and socio-political influence as well as those arising from the contextual factors such as notion of equality, and empowerment of women in household decision-making may be equally important in predicting educational development of NGO beneficiaries.

The study may help in shaping NGO programmes that managers can take necessary actions relating to occupational skill and income generating training development, which in turn, contribute to human capital development.

\section{Conclusion}

Interpreting the relationship between NGOs' socio-economic and training programmes and beneficiaries' educational development is a critical factor in assessing the performance of NGO activities with their ambitious missions and visions. Development is still perceived as a transfer of resources. Based on the conceptual framework, the researcher addressed the research questions through examining the nature of and reasons for the observed disjunction between what NGOs say through their programmes and what they are keen to materialize. The study is underpinned by the study findings that bring insight of socio-economic development of the NGO beneficiaries, particularly the development NGOs in Bangladesh. The findings extend the existing body of knowledge examining the effects of socio-economic and training dimensions towards educational development of NGO clients. The present research, moreover, has empirically supported the human capital theory to be applicable in the context of Bangladesh (Becker, 1964) in explaining the relationships between predictor and outcome variables. In essence, the results affirm that social and some training variables have significant relationships with socio-economic development indicator. Specifically, the NGO managers who concentrate more on minimizing the disjunction between socio-economic and training programmes and education as moral endeavor, the development of their beneficiaries will be high, otherwise, the real socio-economic development of their beneficiaries believed to be loomed large.

\section{References}

Absar, M. M. N., \& Mahmood, M. (2011). New HRM Practices in the Public and Private Sector Industrial Enterprises of Bangladesh: A Comparative Assessment. International Review of Business Research Papers, 7(2), 118-136.

Ahmad, M. M. (2002). Who cares? The personal and professional problems of NGO fieldworkers in Bangladesh. Development in Practice, 12(2), 177-191. http://dx.doi.org/10.1080/09614520220127694

Ahmed, S. (2009). Microfinance institutions in Bangladesh: Achievements and challenges. Managerial Finance, 35(12), 999-1010. http://dx.doi.org/10.1108/03074350911000052

Al-Eisa, A., Furayyan, M., \& Alhemoud, A. (2009). An empirical examination of the effects of self-efficacy, supervisor support and motivation to learn on transfer intention. Management Decision, 47(8), 1221-1244. http://dx.doi.org/10.1108/00251740910984514

Alesina, A., \& Dollar, D. (2000). Who gives foreign aid to whom and why? Journal of Economic Growth, 5, 33-63. http://dx.doi.org/10.1023/A:1009874203400

Alliger, G. M., \& Janak, E. A. (1989). Kirkpatrick's levels of training criteria: Thirty years later. Personnel Psychology, 42, 331-342. http://dx.doi.org/10.1111/j.1744-6570.1989.tb00661.x

Alliger, G. M., Tannenbaum, S. I., Bennett, W. Jr., Traver, H., \& Shotland, A. (1997). A metaanalysis of the relations among training criteria. Personnel Psychology, 50, 341-358. http://dx.doi.org/10.1111/j.1744-6570. 1997.tb00911.x

Arend, E. (2008). Wellness programme and health policy development at a large faith-based organisation in Khayelitsha South Africa. African Journal of AIDS Research, 7(3), 259-270. http://dx.doi.org/10.2989/ AJAR.2008.7.3.3.650

Babbie, E. R. (1995). The Practice of Social Research (7th ed.). London: Wedsworth Publishing.

Barcala, M. F., Martin, A. D., \& Gutierrez, F. T. (2000). Training in retailing: A guide for improving the supply of courses. International Journal of Retail and Distribution Management, 28(6), 243-260. http://dx.doi.org $/ 10.1108 / 09590550010328427$

Barker, A. T. (1997). Determinants of sales force effectiveness: Perceptions of field managers versus senior sales executives. Marketing Intelligence and Planning, 15(6), 258-264. http://dx.doi.org/10.1108/02634509 710184839

Becker, G. S. (1964). Human capital: A theoretical and empirical analysis, with special reference to the 
education. New York: Columbia University Press.

Boissiere, M., Knight, J. B., \& Sabot, R. H. (1985). Earnings, schooling, ability and cognitive skills. American Economic Review, 75(5), 1016-1030.

Breslow, L. (1972). A quantitative approach to the World Health Organization definition of health: Physical, mental and social well-being. International Journal of Epidemology, 1(4), 347-355. http://dx.doi.org/10. 1093/ije/1.4.347

Brown, S., \& Bessant, J. (2003). The manufacturing strategy-capabilities links in mass customization and agile. International Journal of Operations and Production Management, 23(7), 707-730. http://dx.doi.org/10.1108 /01443570310481522

Cronbach, L. J., \& Furby, L. (1970). How should we measure change-or should we? Psychological Bulletin, 74, 68-80. http://dx.doi.org/10.1037/h0029382

Davies, R. (1998). Order and diversity: Representing and assisting organizational learning in non-government aid organizations. $\mathrm{PhD}$ thesis, University of Wales, Bangor.

Denision, E. F. (1962). The Sources of Economic Growth in the United States. New York: National Bureau of Economic Research.

Denison, E. F. (1967). Why growth rates differ: Postwar experience in nine Western countries. Washington, DC: Brookings Institution.

Dhakal, T. N., \& Nawaz, F. (2009). Strategy for Improving Human Capital in Bangladesh and Nepal: Does it help for women empowerment. Paper presented at the Network of Asia-Pacific Schools and Institutes of Public Administration and Governance (NAPSIPAG), Annual Conference, Malaysia.

Dixon, N. M. (1990). The relationship between trainee responses on participant reaction forms and posttest scores. Human Resources Development Quarterly, 1(2), 129-137. http://dx.doi.org/10.1002/hrdq.39200 10204

Dreher, A., Mölders, F., \& Nunnenkamp, P. (2010). Aid delivery through non-governmental organisations: Does the aid channel matter for the targeting of Swedish aid? The World Economy, 33(2), 147-176. http://dx.doi.org/10.1111/j.1467-9701.2009.01233.x

FAO. (1988). Guidelines on socio-economic indicators for monitoring and evaluating agrarian reform and rural development. Rome: FAO, UN.

Fraenkel, J. R., \& Wallen, N. E. (2000). How to design and evaluate research in education. New York: McGraw-Hill.

Fruttero, A., \& Gauri, V. (2005). The Strategic Choices of NGOs: Location Decisions in Rural Bangladesh. Journal of Development Studies, 41(5), 759-787. http://dx.doi.org/10.1080/00220380500145289

Gauri, V., \& Galef, J. (2005). NGOs in Bangladesh: Activities, resources and governance. World Development, 33(12), 2045-2065. http://dx.doi.org/10.1016/j.worlddev.2005.05.009

Giangreco, A., Carugati, A., \& Sebastiano, A. (2010). Are we doing the right thing? Food for thought on training evaluation and its context. Personnel Review, 39(2), 162-177. http://dx.doi.org/10.1108/00483481011 017390

Hair, J. F., Black, W. C., Babin, B. J., \& Anderson, R. E. (2010). Multivariate data analysis: A global perspective (Vol. 7). New Jersey: Prentice Hall.

Hallak, J. (1990). Investing in the Future: Setting Educational Priorities in the Developing World. Paris: UNESCO/IIEO, Pergamon Press.

Haque, M. S. (2002). The changing balance of power between the government and NGOs in Bangladesh. International Political Science Review, 23(4), 411-435. http://dx.doi.org/10.1177/0192512102023004006

Holton, E. F. (2005). Holton's evaluation model: New evidence and construct elaborations. Advances in Developing Human Resources, 7(1), 37-54. http://dx.doi.org/10.1177/1523422304272080

Huda, K., Karim, M., \& Ahmed, F. (2007). HRM practices and challenges of non-government development organizations: An empirical study on Bangladesh. Journal of Management, 9(1), 35-49.

Hulme, D. (2000). Impact assessment methodologies for microfinance: Theory, experience and better practice. World Development, 28(1), 79-98. http://dx.doi.org/10.1016/S0305-750X(99)00119-9 
Jadad, A. R., \& O'Grady, L. (2008). How should health be defined? BMJ, 337, a2900. http://dx.doi.org/10.1136 /bmj.a2900

Jaffee, D. (1998). Levels of Socio-Economic Development Theory (2nd ed.). Westport, CT: Praeger Publishers.

Jahur, M. S., Absar, M. M. N., \& Sultana, T. (2002). The role of NGOs in human resource development in Bangladesh-An evaluative study. Paper presented at the Human Resource Development in Asia: Trends and Challenges, AHRDI, USA and AHRD, India.

Jalan, J., \& Ravallion, M. (1998). Transient poverty in rural China. Journal of Comparative Economics, 26(2), 338-357. http://dx.doi.org/10.1006/jcec.1998.1526

Katayama, H. (2007). Education for all-fast track initiative: The donors' perspectives. PhD thesis, University of Pittsburgh, Pennsylvania, USA.

Khan, M. A., \& Ali, A. J. (2014). The role of training in reducing poverty: The case of the ultra-poor in Bangladesh. International Journal of Training and Development, 18(4). Epub ahead of print 25 September 2014. http://dx.doi.org/10.1111/ijtd.12041

Khandker, S. (1999). Fighting poverty with microcredit: Experience in Bangladesh. Dhaka, Bangladesh: The University Press Limited.

Kirkpatrick, D. (1998). Evaluating training programs-The four levels (2nd ed.). San Francisco, CA: Berret-Koehler Publisher.

Kirkpatrick, D. (2005). Evaluating training program: The four levels (3rd ed.). Williston, US: Berrett-Koehler Publishers.

Krein, K. J., \& Weldon, K. (1994). Making a play for training evaluation. Training and Development, 48(4), 62-67.

Krugman, P. (1994). The myth of Asia's miracle. Foreign affairs, 73, 62-78. http://dx.doi.org/10.2307/20046929

Mahmood, M. (2004). The institutional context of human resource management: Case studies of multinational subsidiaries in Bangladesh. Doctoral dissertation, University of Manchester, UK.

McEvoy, G. M. (1997). Organizational change and outdoor management education. Human Resource Management, 36(2), 235-250. http://dx.doi.org/10.1002/(SICI)1099-050X(199722)36:2<235::AID-HRM5> 3.0.CO;2-Y

McGranahan, D. V., Richard-Proust, C., Sovani, N. V., \& Subramanian, M. (1972). Contents and measurement of socioeconomic development. New York, N. Y.: Praeger.

McLean, G. N. (2005). Examining approaches to HR evaluation: The strengths and weaknesses of popular measurement methods. Strategic Human Resources, 4(2), 24-27.

Moe, T. L. (2008). An empirical investigation of relationships between official development assistance (ODA) and human and educational development. International Journal of Social Economics, 35(3), 202-221. http://dx.doi.org/10.1108/03068290810847879

Nabi, K. A., Alam, J., Jahur, M. S., \& Quadir, S. M. N. (1997). Grameen Bank and Socio-Economic Changes-A Study of Selected Loanees. Dhaka, Bangladesh: German Cultural Centre-Goethe-Institut.

Nardi, P. (2003). Doing survey research: A guide to quantitative research methods. New York: Pearson Allyn and Bacon.

Noe, A. R. (2008). Employee Training and Development (4th ed.). New York: McGraw-Hill.

Nunnally, J. C. (1978). Psychometric theory (2nd ed.). New York: McGraw-Hill.

O’Driscoll, M. P., Brough, P., \& Kalliath, T. J. (2004). Work/family conflict, psychological well-being, satisfaction and social support: A longitudinal study in New Zealand. Equal Opportunities International, 23(1/2), 36-56. http://dx.doi.org/10.1108/02610150410787846

Pau, C. K. F. (2001). Factors Contributing Training Effectiveness, MBA Research Report: School of Management. University Sains Malaysia, Penang.

Pitt, M. M., Khandker, S. R., Chowdhury, O. H., \& Millimet, D. L. (2003). Credit programs for the poor and the health status of children in rural Bangladesh. International Economic Review, 44(1), 87-118. http://dx.doi. org/10.1111/1468-2354.t01-1-00063

Price, J. L. (2001). Reflection on the determinants of voluntary turnover. International Journal of Manpower, 


\section{2(7), 600-624. http://dx.doi.org/10.1108/EUM0000000006233}

Psacharopoulos, G. (1994). Returns to investment in education: A global update. World Development, 22(8), 1325-1343. http://dx.doi.org/10.1016/0305-750X(94)90007-8

Rahman, A. F. M. A. (2005). The transformation of spaces for home based income generation: An approach towards economic subsistence for the urban poor at Khulna slums. M.ScUP thesis, University of Hong Kong, Hong Kong.

Ramlall, S. (2004). A review of employee motivation theories and their implications for employee retention within organizations. Journal of American Academy of Business, 5(1/2), 52.

Rao, M. V. S. (1976). Socio-economic indicators for development planning. In UNESCO (Ed.), The use of socio-economic indicators in development planning. The UNESCO press.

Rees, A. (1979). The economics of work and pay (2nd ed.). New York: Harper and Row.

Rossi, P. H., \& Freeman, H. E. (1989). Evaluation: A Systematic Approach. Newbury Park, CA: Sage.

Schiere, R. (2008). Vulnerability, public service delivery and fiscal decentralization: The experience of china as a developing and a transition country. $\mathrm{PhD}$ thesis, University of Auvergne, France.

Schultz, T. W. (1963). The economic value of education (Vol. 63). New York: Columbia University Press.

Sekaran, U. (2003). Research methods for business-A skill building approach (4th ed.). USA: John Willey and Sons.

Sekaran, U., \& Bougie, R. (2010). Research methods for business-A skill building approach (5th ed.). London: John Willey and Sons.

Sen, B. (2003). Drivers of escape and descent: Changing household fortunes in rural Bangladesh. World Development, 31(3), 513-534. http://dx.doi.org/10.1016/S0305-750X(02)00217-6

Tai, W. T. (2006). Effects of training framing, general self-efficacy and training motivation on trainees' training effectiveness. Personnel Review, 35(1), 51-65. http://dx.doi.org/10.1108/00483480610636786

Ullah, A. K. M. A., \& Routray, J. K. (2007). Rural poverty alleviation through NGO interventions in Bangladesh: How far is the achievement? International Journal of Social Economics, 34(4), 237-248. http://dx.doi.org/ $10.1108 / 03068290710734208$

UNICEF. (1999). The state of the world's children. New York: UNICEF.

Wagstaff, A. (2002). Poverty and health sector inequalities. Bulletin-World Health Organization, 80(2), 97-105.

WHO. (2006). Constitution of the World Health Organization. Retrieved October 10, 2011, from http://www.who.int/governance/eb/who_constitution_en.pdf

Wilson, H. C. (2000). Emergency response preparedness: Small group training. Part I-training and learning styles. Disaster Prevention and Management, 9(2), 105-116. http://dx.doi.org/10.1108/09653560010326987

Xu, K., Evans, D. B., Kawabata, K., Zeramdini, R., Klavus, J., \& Murray, C. J. L. (2003). Household catastrophic health expenditure: A multicounty analysis. The Lancet, 362(9378), 111-117. http://dx.doi.org /10.1016/S0140-6736(03)13861-5

Zaman, H. (1996). Microcredit programme: Who participates and to what extent? BRAC-ICDDR, B. joint research project, Working Paper No. 12, Dhaka.

Zaman, H., Annamalai, N., Irajen, A. R., \& Frank. (2005). The economics and governance of non-governmental organizations (NGOS) in Bangladesh. Poverty Reduction and Economic Management Sector Unit South Asia Region, document of the World Bank consultation draft. Retrieved January 5, 2011, from http://www.lcgbangladesh.org/ngos/reports/ngo_report_clientversion.pdf

\section{Copyrights}

Copyright for this article is retained by the author(s), with first publication rights granted to the journal.

This is an open-access article distributed under the terms and conditions of the Creative Commons Attribution license (http://creativecommons.org/licenses/by/3.0/). 